\title{
The Development of the Artist-Fan Engagement Model
}

\author{
Sarita M. Stewart \\ Belmont University \\ This paper was presented at the 2019 International Summit of the \\ Music \& Entertainment Industry Educators Association \\ March 21-23, 2019
}

https://doi.org/10.25101/19.34

\begin{abstract}
In an industry where the music consumer has unprecedented access and prefers ongoing interaction with music artists, it is important to identify how these relationships can be best leveraged. This would include engagement between a music artist and their fans through various social media platforms (e.g., Facebook, Instagram, Pinterest, Snapchat, Twitter, Tumblr, YouTube, etc.). The Artist-Fan Engagement Model was developed as a theoretical framework to help explain this relationship between music artists and their fans. The model, created using hedonic consumption and parasocial interaction theory (PSI) as its foundational underpinnings, explores how the effects of music and artist help drive fan engagement, whether through access or ownership of recorded music.

The development of the Artist-Fan Engagement Model, along with the initial study results from 2012, is discussed. However, given the sweeping changes within the music industry since the time of the original study, various components of the model are now being revised to better reflect current market realities. A second round of research is planned for late 2019 with the goal being to determine how the research outcomes have changed since the initial study was conducted.
\end{abstract}

Keywords: artist, fan, engagement, recorded music, marketing.

This paper is published in the International Journal of Music Business Research Vol. 7, No. 2 (October 2018). https:// musicbusinessresearch.files.wordpress.com/2018/10/volume-7-no-2-october-2018_stewart_final.pdf.
Sarita M. Stewart is an Associate Professor of Entertainment Industry Studies in the Mike Curb College of Entertainment \& Music Business at Belmont University. Stewart's teaching expertise is in the area of public relations, music marketing, and consumer research. Her main research focus is on the topic of music consumption, with accompanying interests in the areas of video games, social media, and mood management. Dr.

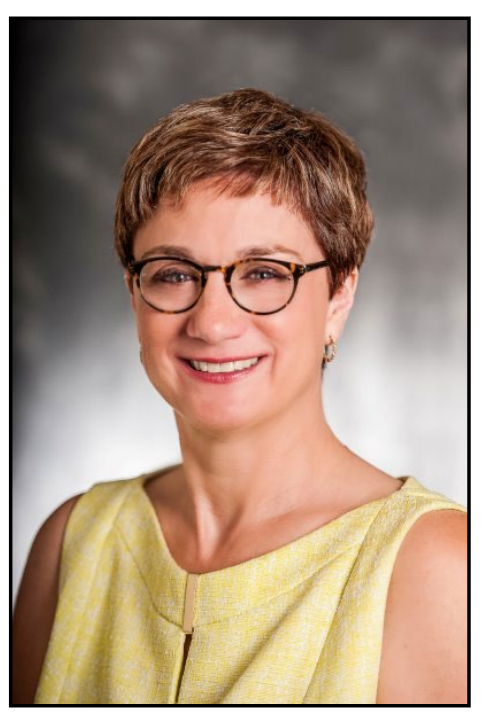
Stewart's publications include an essay on LeAnn Rimes' album Blue in Please Allow Me To Introduce Myself: Essays on Debut Albums (Ashgate), and book chapter, "TV, Radio, and Music Research," in Research Methods in Communication (Third Edition) (Vision Press). Stewart, along with her co-authors Maria Ivey of IVPR and Dorren Robinson (Belmont University) are preparing a textbook: Music Publicity: A Practical Approach, scheduled to be published by Kendall Hunt in Fall 2019. Additionally, Stewart serves as a book editor of the Springer International Music Business Research Series. She also participates as a panelist at numerous academic and industry conferences. Stewart's entertainment industry experience includes a thirteen-year stint at Curb Records where she served as Director of Marketing, and AKG Acoustics, as U.S. Marketing Manager. Stewart holds a B.S. in Business Administration from Oregon State University, Masters in Business Administration from the Drucker School of Management at Claremont Graduate University, and a Ph.D. from The University of Alabama. She is a 2017 graduate of Leadership Music. 


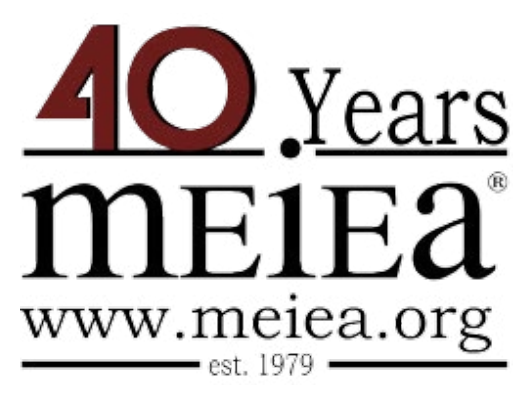

\section{PROCEEDINGS OF THE \\ 2019 INTERNATIONAL SUMMIT \\ OF THE \\ MUSIC \& ENTERTAINMENT \\ INDUSTRY EDUCATORS \\ ASSOCIATION}

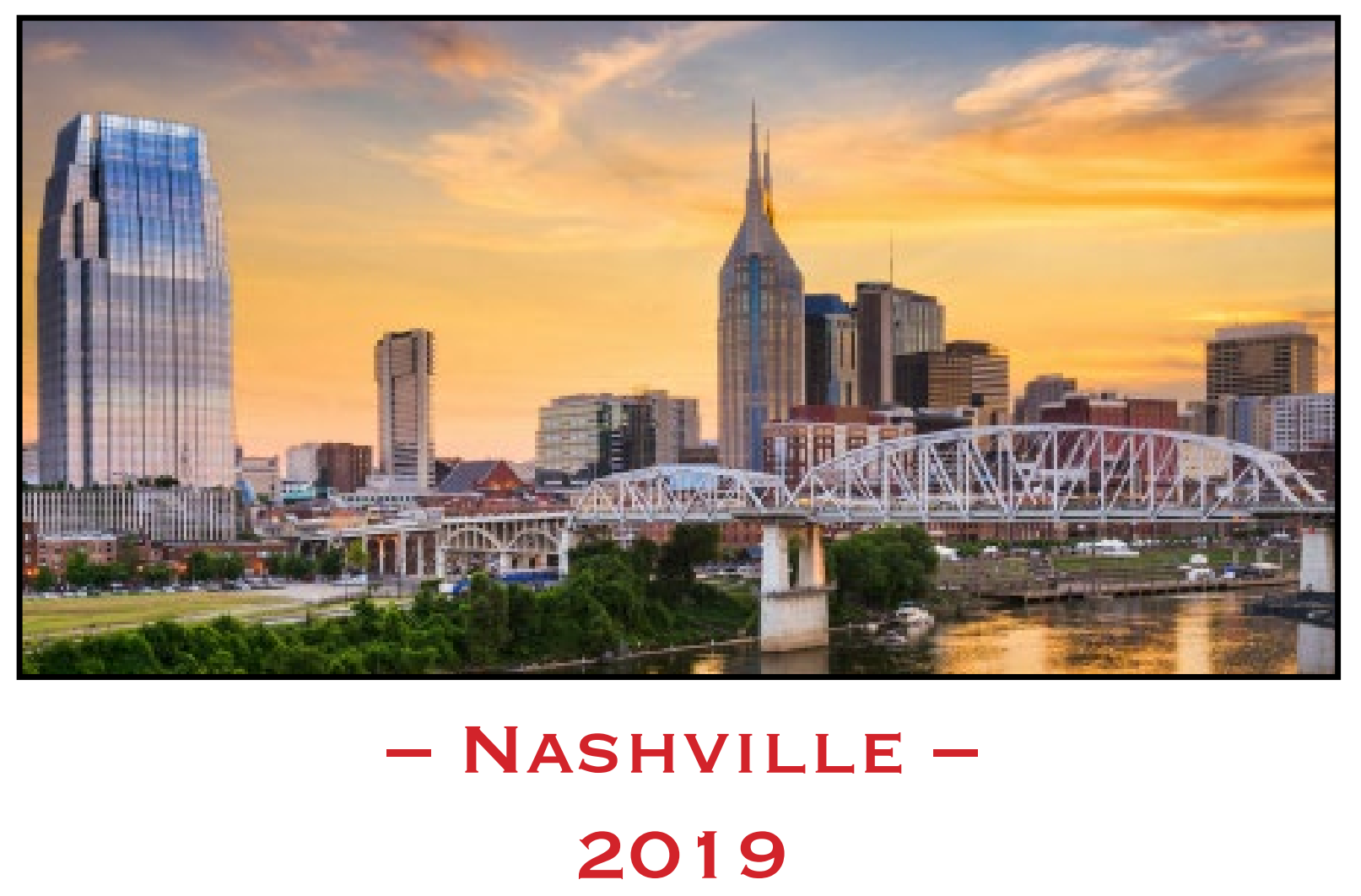

March 21 - 23, $2019 \cdot$ Belmont University - Nashville 